\section{THU0051 PROLIFERATION AND STABILITY OF CYTOKINE EXPRESSION OF IL-4 OR IL-10 SECRETING T HELPER CELLS}

${ }^{1} \mathrm{AH}$ Radbruch, ${ }^{1} \mathrm{M}$ Loehning, ${ }^{1} \mathrm{~A}$ Richter, ${ }^{1} \mathrm{~T}$ Stamm, ${ }^{1} \mathrm{O}$ Soezeri, ${ }^{1} \mathrm{HD}$ Chang, ${ }^{1} \mathrm{~L}$ Tykocinski, ${ }^{2} \mathrm{M}$ Assenmacher. 'Cell Biology, Deutsches Rheuma-Forschungszentrum Berlin (DRFZ), Berlin, Germany; ${ }^{2}$ Miltenyi Biotec GmbH, Bergisch Gladbach, Germany

\subsection{6/annrheumdis-2001.848}

Background The cytokines IL-4 and IL-10 have been implicated in the regulation of $\mathrm{T}$ cell proliferation and differentiation. IL-4 drives the development of Th2 cells from naive precursors and it is supposed to enhance T cell proliferation, whereas IL-10 has been suggested to support the differentiation of regulatory $\mathrm{Th}$ cells and to negatively affect $\mathrm{T}$ cell proliferation.

Objectives To analyse the proliferation and stability of cytokine expression of individual cytokine-producing T cells.

Methods We established the cellular affinity matrix technology for the immunofluorescent identification and isolation of IL-4or IL-10-secreting cells. With this technology we purified IL-4or IL-10-secreting and non-secreting Th cells, labelled them with the fluorescent dye CFSE to track their proliferation after antigen-specific or polyclonal restimulation, and analysed their cytokine expression upon later restimulation.

Results Previously, we have shown that naive Th cells have to enter the initial $S$ phase of the first cell cycle to respond to an IL-4 signal by production of IL-4 or IL-10 upon restimulation. By direct counterstaining of cytokines and DNA content we now tested whether in general cytokine production is restricted to certain cell cycle phases, which we found not to be the case. The isolated IL-4+ and IL-4- T cells showed the same proliferation behaviour over 6 days, and the sorted IL-10+ cells were not inhibited in their proliferation compared with the IL-10- T cells. Thus, neither IL-4 nor IL-10 production by an individual T cell directly influences the proliferation of the same cell. When we analysed the stability of cytokine memory of the sorted T cells in later restimulations, a substantial fraction of the purified cytokine-producing cells did not reexpress the cytokine that it had expressed in an earlier stimulation.

Conclusion Thus, there is a certain degree of instability in the cytokine memory of Th cells, the molecular basis of which we are currently analysing.

\section{THU0052 HEPARIN AFFIN REGULATORY PEPTIDE (HARP) IN ACUTE AND CHRONIC ARTICULAR DISEASES}

${ }^{1} \mathrm{M}$ Héroult, ${ }^{2} \mathrm{~F}$ Lioté, ${ }^{2} \mathrm{R}$ Champy, ${ }^{1} \mathrm{D}$ Barritault, ${ }^{1} \mathrm{~J}$ Courty. ' Laboratoire de Recherche Sur La Croissance Cellulaire, La Réparation Et La Régénération Tissulaires (CRRET), UPRES-a CNRS 7053, Université Paris XII-Val de Marne, Creteil, France; '2Laboratoire de Radiologie Expérimentale Et de Physiopathologie Articulaire (JE2149) (Centre Viggo Petersen), Université Paris VII and Hôpital Lariboisière (Assistance Publique-Hôpitaux de Paris [AP-HP]), Paris, France

10.1136/annrheumdis-2001.849

Background Heparin affin regulatory peptide (HARP), also known as pleiotrophin (PTN) is a potent mitogen for various cell types and an angiogenic polypeptide implicated in tumour development. $^{1-4}$

Objectives Since the progression of the pannus is associated with angiogenic processes and synovial membrane hypertrophy, ${ }^{5,6}$ the involvement of HARP in comparison with two other growth factors including MK and VEGF in rheumatoid pathologies was investigated.
Methods Presence of HARP in human synovial fluids and sera from patients was investigated by immunoassay. The distribution of HARP mRNA and protein was studied by in situ hybridization and immunohistochemistry respectively.

Results Comparative analysis showed that HARP as well as MK concentrations were significantly higher $(p<0.001)$ in synovial fluids from patients with inflammatory arthritis including rheumatoid arthritis $(\mathrm{n}=14)$, ankylosing spondylitis $(\mathrm{n}=8)$, chondrocalcinosis $(n=7)$ and gout $(n=11)$ than from patients with osteoarthritis $(n=29)$. In contrast, no significant difference was observed between inflammatory and non inflammatory diseases for VEGF. In addition, serum HARP and MK concentrations were significantly higher in patients with arthritis $(\mathrm{n}=37)$ than in normal subjects $(\mathrm{n}=18)(\mathrm{p}<0.001)$. Immunohistological studies demonstrated HARP within the synovial lining cells, endothelial cells of new capillaries, and macrophages of inflammatory synovial tissue. In situ hybridization studies revealed that synovial lining cells and vascular endothelial cells expressed high levels of HARP mRNA.

Conclusion These results suggest that HARP, in concert with other cytokines and growth factors, may play a role in the pathophysiology of acute and chronic synovitis in conditions such as crystal-induced arthritis and rheumatoid arthritis, respectively.

\section{REFERENCES}

1 Li YS, Milner PG, Chauhan AK, Watson MA, Hoffman RM, Kodner CM, Milbrandt J, Deuel TF. Science 1990;250:1690-4

2 Courty J, Dauchel MC, Caruelle D, Pederiset M, Barritault D. Biochem Biophy Res Commun. 1991:180:145-51

3 Bernard-Pierrot I, Delbé J, Caruelle D, Barritault D, Courty J. J Biol Chem. in press

4 Choudhuri R, Zhang HT, Donnini S, Ziche M, Bicknell R. Cancer Res. 1997:57:1814-19

5 Peacok DJ, Banquerigo ML, Brahn E. J Exp Med. 1992;175:1135-8

6 Koch AE. Ann Rheu Dis. 2000;59(Suppl 1):165-71

\section{THU0053 INHIBITION OF ARACHIDONIC ACID RELEASE FROM HUMAN PERIPHERAL MONONUCLEAR CELLS BY HEAT SHOCK TREATMENT AND GELDANAMYCIN}

S Szanto, P Csermely, I Kovács, J Csongor, GY Szegedi, S Sipka. Third Department of Medicine, University of Debrecen, Debrecen, Hungary

10.1136/annrheumdis-2001.850

Background Arachidonic acid and its derivatives play an important role in inflammation including arthritis.

Objectives To investigate the effects of heat shock (HS) treatment and geldanamycin (GM) on the release of arachidonic acid (AA) from human peripheral blood human mononuclear cells (PBMCs) (monocytes and lymphocytes).

Methods Mononuclear cells prepared from blood of healthy subjects were preincubated with $3 \mathrm{H}-\mathrm{AA}$. The release of $3 \mathrm{H}-\mathrm{AA}$ incorporated into the membrane was studied after pretreatment of cells by $\mathrm{HS}\left(43^{\circ} \mathrm{C}, 1 \mathrm{~h}\right), \mathrm{GM}$ and prednisolone sodium succinate (PRED). The activation of AA producing enzymes took place by the addition of phorbol 12-myristate 13-acetate (PMA) or by the combination of PMA and calcium ionophore A 23187. Results The release of AA by mononuclear cells was dose dependently inhibited by GM similarly to PRED. The treatment of cells by HS also inhibited the release of AA. An additivity was found in the inhibitions induced by GM, PRED and HS.

Conclusion HS treatment can decrease the release of AA from human mononuclear cells. GM also results in a dose dependent inhibition of AA release. In the mechanism of additivity In the mechanism of additivity found when HS and GM were applied 